\title{
Long-Term Toxicological Monitoring of a Multibarrier Advanced Wastewater Treatment Plant Comprising Ozonation and Granular Activated Carbon with In Vitro Bioassays
}

 \\ Peter A. Behnisch ${ }^{4}\left(\right.$ and Norbert Kreuzinger ${ }^{1}$ \\ 1 Institute for Water Quality and Resource Management, TU Wien, Karlsplatz 13/226-1, 1040 Vienna, Austria; \\ lam.thanh@tuwien.ac.at (L.T.P.); daniela.reif@tuwien.ac.at (D.R.); sascha.weilguni@gmail.com (S.W.); \\ ernis.saracevic@tuwien.ac.at (E.S.); joerg.krampe@tuwien.ac.at (J.K.); norbkreu@iwag.tuwien.ac.at (N.K.) \\ 2 Faculty of Environment and Natural Resources, Ho Chi Minh City University of Technology (HCMUT), \\ 268 Ly Thuong Kiet Street, District 10, Ho Chi Minh City 70000, Vietnam \\ 3 Viet Nam National University Ho Chi Minh City, Linh Trung Ward, Ho Chi Minh City 70000, Vietnam \\ 4 BioDetection Systems bv, Science Park 406, 1098 XH Amsterdam, The Netherlands; Peter.Behnisch@bds.nl \\ * Correspondence: heidemarie.schaar@tuwien.ac.at
}

check for updates

Citation: Phan, L.T.; Schaar, H.; Reif, D.; Weilguni, S.; Saracevic, E.; Krampe, J.; Behnisch, P.A.; Kreuzinger, N. Long-Term Toxicological Monitoring of a Multibarrier Advanced Wastewater Treatment Plant Comprising Ozonation and Granular Activated Carbon with In Vitro Bioassays. Water 2021, 13, 3245. https://doi.org/ $10.3390 /$ w13223245

Academic Editors: Martin Wagner and Sonja Bauer

Received: 29 September 2021 Accepted: 13 November 2021 Published: 16 November 2021

Publisher's Note: MDPI stays neutral with regard to jurisdictional claims in published maps and institutional affiliations.

Copyright: () 2021 by the authors. Licensee MDPI, Basel, Switzerland. This article is an open access article distributed under the terms and conditions of the Creative Commons Attribution (CC BY) license (https:// creativecommons.org/licenses/by/ $4.0 /)$.

\begin{abstract}
A set of CALUX in vitro bioassays was applied for long-term toxicity monitoring at an advanced wastewater treatment plant comprising ozonation and granular activated carbon filtration for the abatement of contaminants of emerging concern (CEC). During the 13-month monitoring, eight reporter gene assays targeting different modes of action along the cellular toxicity pathway were accessed to evaluate the suitability and robustness of the technologies. Two approaches were followed: on the one hand, signal reduction during advanced treatment was monitored; on the other hand, results were compared to currently available effect-based trigger values (EBTs). A decrease of the corresponding biological equivalent concentrations after the multibarrier system could be observed for all modes of action; while the estrogenic activity decreased below the EBT already during ozonation, the potencies of oxidative stress-like and toxic PAH-like compounds still exceeded the discussed EBT after advanced treatment. Overall, the long-term monitoring confirmed the positive effect of the multibarrier system, commonly evaluated only by CEC abatement based on chemical analysis. It could be demonstrated that advanced WWTPs designed for CEC abatement are suitable to significantly decrease toxicity responses not only in the frame of pilot studies but under real-world conditions as well.
\end{abstract}

Keywords: ozonation; granular activated carbon; CALUX reporter gene bioassays; effect-based trigger value; urban wastewater

\section{Introduction}

The amount and diversity of chemicals in use by our modern society are constantly increasing, reaching 156 million chemicals in 2019, according to the statistics of the chemical abstracts service of the American Chemical Society [1]. A wide variety of these substances enter the water cycle via sewerage and wastewater treatment plants after application and use [2], where they are considered contaminants of emerging concern (CEC). CEC may have been present in the aquatic environment in the past, but only recently have concerns been raised about their potential ecological or human health impacts. In this paper, CEC refers to organic trace substances present in the low microgram to nanogram per liter concentration range. Currently, applied best available technologies (BAT) for conventional biological wastewater treatment cover carbon and nutrient removal. However, these wastewater treatment plants (WWTPs) are not designed to target organic trace compounds, thus resulting in a release into the environment in line with diverse substance-specific removal patterns [3]. 
The current European Union legislative framework to assess water quality for wastewater and surface water goes back to 1991 and 2000, respectively [4,5]. Then, impacts on aquatic systems were still dominated by carbon and nutrient pollution, while CEC were of no immediate concern. Despite the implementation of follow up amendments, e.g., by directives on environmental quality standards (EQS) and the EU watch list [6-9], an approach to adequately deal with the increasing number, diversity, and change of chemical substances in use did not exist until now [10].

During the last decade, upgrading conventional biological WWTPs for CEC abatement by ozonation or activated carbon proved feasible and financially affordable [11]. Thus, these advanced treatment steps can be implemented on a short- to mid-term scale. Despite existing technical solutions, the issue of required removal efficiencies and linked treatment goals is still pending, since current criteria and approaches based on single chemical analyses are not fit to tackle the chemical diversity of known and yet unknown CEC in water. However, defining robust treatment targets is of paramount significance for developing technical solutions and their resource-efficient operation, especially since single substance analysis does not cover the biological effects of unknown substances (including metabolites) and mixtures [1].

In contrast to single chemical analysis, effect-based methods (EBMs) with bioanalytical tools can account for mixture effects of known and unknown compounds showing common modes of action (MOA) $[1,12,13]$. Thus, bioassays can be applied to quantify a specific biological effect without knowing its chemical composition. Nowadays, a wide variety of cell-based in vitro bioassays is available, and there are no ethical issues compared to in vivo testing [10,14-16]. Methodological synergies for chemical analysis and sample preparation for EBMs such as enrichment and extraction steps and the possibility of high throughput analysis further helped to increase acceptance and applicability. Due to these advances, EBMs are increasingly applied for water quality assessment, ranging from drinking water to environmental samples such as surface water and wastewater [17-19]. Thus, in vitro bioassays are suitable analytical tools to quantify mixture effects since they are, per definition, detecting the impact of all chemicals inducing the same toxicity endpoint in a given MOA-specific bioassay.

EBMs yield quantitative effect measures that can be translated into biological equivalent concentrations (BEQ). As an example for EBMs, estrogenic activity as one of the most relevant MOA for endocrine disruption [19] can be given. Estrogenic effects in water can be attributed to the occurrence of steroidal estrogens, e.g., 17 $\beta$-estradiol (E2) or 17 $\alpha$ ethinylestradiol, and industrial chemicals, e.g., bisphenol A (BPA, cf. [20]) or nonylphenols. Results for EBMs are given in BEQ, in the case of estrogenicity, calibrated to E2 equivalents (ng/L). By definition, 1 ng of E2 has a relative effect potency (REP) of one. Less active substances such as BPA have a molar REP of $1.95 \times 10^{-5}$ [10], meaning the effect is approximately five orders of magnitude less potent than E2. Therefore, the bioassay result in E2 equivalents gives an integrated view of the summary effect for all estrogenic chemicals in the water as if evoked only by E2. As an advantage, even unknown estrogenic compounds are assessed, and chemical multi-target analysis can be avoided.

Only recently, discussions on the implementation of EBMs in the EU Water Framework Directive have started $[18,21,22]$, together with the development of linked environmental quality standards (EQS). In that regard, several authors [10,22-24] developed and proposed effect-based trigger values (EBT), which help differentiate acceptable and unacceptable effect levels for different MOA. These EBT form an essential base for the implementation of EBMs into the regulatory framework. Reviewing the current status and immediate applicability of effect-based assays for assessing risks associated with the reuse of treated wastewater, the COST action NEREUS (EU-COST Action ES 1403) proposed including bioassays in monitoring programs for WWTP effluents. A suggested bioassay battery and EBT from the literature were published in the joint NORMAN and Water Europe Position paper "New and emerging challenges and opportunities in wastewater reuse" [25]. 
Implementing EBMs and advanced treatment steps address organic CEC and their mixture but with a different focus. Whereas EBMs quantify effects of mixture toxicity, advanced treatment tackles these effects from the causative substance-specific side by decreasing reactive known and yet unknown chemical agents. This makes it obvious to link both approaches by using in vitro bioassays with their linked EBTs as treatment goals and quality criteria for designing, operating, and evaluating advanced wastewater treatment. So far, most investigations on advanced treatment technology assessment with bioassays [26-28] were conducted on lab- or pilot-scale plants operated by scientific staff over a comparably short period with high control efforts. Despite the successful combination of EBMs and advanced treatment technologies, a routine application under real-life conditions with fluctuations of the wastewater, operational, technical and maintenance failures, resulting in suboptimal operation of technologies and therefore out-of-target efficiency is still not considered.

The overall objective of the present study was the long-term toxicological monitoring of multibarrier advanced wastewater treatment under actual conditions, applying a MOAbased in vitro bioassay battery to target relevant toxicological endpoints. After installation, setup of a proper and robust operation, and training, the WWTP operators were committed to integrating the plant operation into their daily routine. Monthly routine monitoring samplings over one year formed the basis to assess the performance and suitability of the applied technologies for broader implementation.

\section{Materials and Methods}

\subsection{Sampling Site and Advanced Wastewater Treatment Plant}

The sampling site was located at a municipal wastewater treatment plant (7250 p. e.) with a conventional activated sludge process, including full nitrification/denitrification, and phosphorus removal. This corresponds to the best available technologies for biological wastewater treatment in Austria and to the requirements for eutrophication-sensitive areas according to the EU urban wastewater treatment directive [5]. Over the period investigated, the mean chemical oxygen demand (COD) and dissolved organic carbon (DOC) concentrations in the WWWTP effluent were $14.85 \pm 2.67 \mathrm{mg} / \mathrm{L}$ and $4.26 \pm 0.49 \mathrm{mg} / \mathrm{L}$, respectively. The nutrient concentrations averaged $0.62 \pm 1.25 \mathrm{mg} / \mathrm{L}$ for ammonia $\left(\mathrm{NH}_{4}-\mathrm{N}\right)$, $0.75 \pm 0.55 \mathrm{mg} / \mathrm{L}$ for nitrate $\left(\mathrm{NO}_{3}-\mathrm{N}\right)$, and $0.08 \pm 0.08 \mathrm{mg} / \mathrm{L}$ for nitrite nitrogen $\left(\mathrm{NO}_{2}-\mathrm{N}\right)$. The mean daily wastewater flow was $1540 \pm 612 \mathrm{~m}^{3} / \mathrm{d}$. The WWTP treats wastewater from a combined sewer system. In case of a stormwater event, wastewater exceeding the hydraulic design capacity of the plant is pumped to rainwater basins and afterward continuously treated according to the hydraulic capacity. The treatment plant's effluent is buffered in a basin, which serves as a feed tank for the advanced treatment plant.

Figure 1 shows the flow scheme of the multibarrier system comprising ozonation and granular activated carbon filtration. The advanced treatment demonstrator plant is on transition of the technical readiness level (TRL) 7 to 8 . The three ozone reactors operated in series had a total volume of $12 \mathrm{~m}^{3}$ and the hydraulic retention time varied between 9 and $40 \mathrm{~min}$, depending on the inflow dynamics of wastewater. The activated carbon filter was filled with $1.8 \mathrm{~m}^{3}$ of granular activated carbon (GAC), type Epibon A (Donau Carbon, Frankfurt, Germany) and treated a side stream of $8 \mathrm{~m}^{3} / \mathrm{h}$, which resulted in an empty bed contact time of $13.5 \mathrm{~min}$. During routine operation a specific nitrite compensated ozone dose $\left(D_{\text {spec }}\right)$ of $0.55 \mathrm{~g} \mathrm{O}_{3} / \mathrm{g}$ DOC was targeted in the automated process control system that was based on a UV-DOC-correlation model and continuous UV absorption measurement. A posteriori it ranged between 0.4 and $0.7 \mathrm{~g} \mathrm{O}_{3} / \mathrm{g}$ DOC. For specific research campaigns the specific ozone dose was varied between 0.2 and $0.9 \mathrm{~g} \mathrm{O}_{3} / \mathrm{g}$ DOC. The sampled bed volumes (BV) of the granular activated carbon filter ranged from approx. 1000 (start of monitoring) to 33,100 (final sampling campaign). 


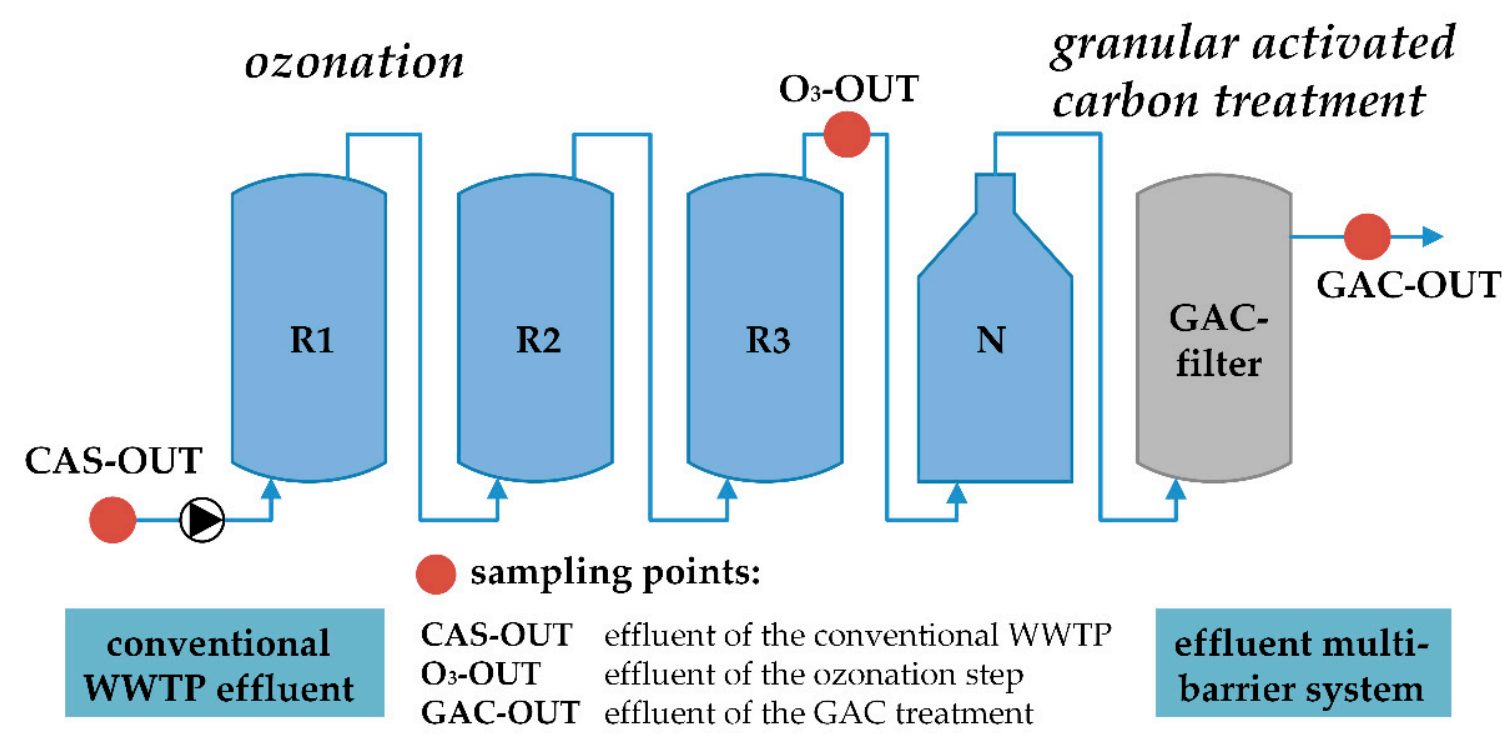

Figure 1. Flow scheme of the advanced treatment demonstrator plant with sampling points (CAS: conventional activated sludge, R: ozone reactor, N: feed tank for GAC-filter, GAC: granular activated carbon).

\subsection{Sampling Campaigns}

A monthly routine monitoring was performed between May 2018 and May 2019, including all three sampling points indicated in Figure 1. Additionally, two scientific research campaigns were conducted to evaluate the impact of a broader dose range on the toxicity by comparing the inlet and outlet of the ozonation step. After assessing the sampling type, it was decided to take all samples as grab samples in $1.5 \mathrm{~L}$ aluminum bottles, according to the recommendations of BioDetection Systems BV (Amsterdam, The Netherlands). Over the sampling period of 13 months, 16 samples were taken, see Table S1.

\subsection{Sample Extraction for Bioanalysis}

All wastewater samples were filtered through a glass fiber filter (pore size $3 \mu \mathrm{m}$ ), and the maximum sample volume after filtration was $1000 \mathrm{~mL}$.

The samples were concentrated by solid-phase-extraction (SPE) with Oasis HLB cartridges (500 mg, 6cc, Waters 186000115; Waters Corporation, Taunton, MA, USA) according to the described protocol of BioDetection Systems bv (Amsterdam, The Netherlands) with slight modifications regarding the final resuspension of the sample that had been evaporated to dryness. The cartridges were pre-conditioned with $6 \mathrm{~mL}$ acetonitrile and $6 \mathrm{~mL}$ deionized water, both of which were drawn through the cartridges under a low vacuum with a vacuum manifold to remove residual bonding agents. The filtered samples were loaded onto the cartridge under a slight vacuum; the flow over the cartridge was adjusted to a few drops per second to avoid exceeding $10 \mathrm{~mL} / \mathrm{min}$. After loading, the cartridges were washed with $6 \mathrm{~mL} \mathrm{5 \%} \mathrm{methanol} \mathrm{(w/w)} \mathrm{and} \mathrm{then} \mathrm{dried} \mathrm{for} 30 \mathrm{~min}$ under vacuum to remove excess water remaining on the cartridge. Subsequently, the adsorbed analytes were eluted from the cartridges to a $20 \mathrm{~mL}$ culture tube with $10 \mathrm{~mL}$ methanol and $10 \mathrm{~mL}$ acetonitrile at a flow rate of approx. $5 \mathrm{~mL} / \mathrm{min}$. Afterward, the samples were evaporated to dryness $( \pm 0.5 \mathrm{~mL})$ under a stream of nitrogen at room temperature. This volume was transferred from the culture tube to the vial and rinsed with $0.5 \mathrm{~mL}$ methanol and $0.5 \mathrm{~mL}$ acetonitrile. The final volume of $1.5 \mathrm{~mL}$ extracted sample was kept in the fridge at $7{ }^{\circ} \mathrm{C}$ before analysis.

\subsection{Bioassays}

The wastewater extracts were analyzed by BioDetection Systems bv (Amsterdam, The Netherlands) with nine CALUX (Chemical Activated Luciferase eXpression) reporter 
gene bioassays. The principle of the bioassay is described in [29], and the corresponding key references are given in Table S2.

The in vitro bioassay test battery was designed to target MOA based on well-defined toxic mechanisms that cover relevant steps along the cellular toxicity pathway as recommended in the literature $[10,13,14]$, see Figure 2. Even though positive signal responses cannot be directly translated into higher-order effects, every adverse outcome begins with a molecular initiating event. It demonstrates the link between biological response at the cellular level with higher-order effects on the organ, followed by the organism and eventually the population level, which is summarized under the concept of adverse outcome pathways [30].

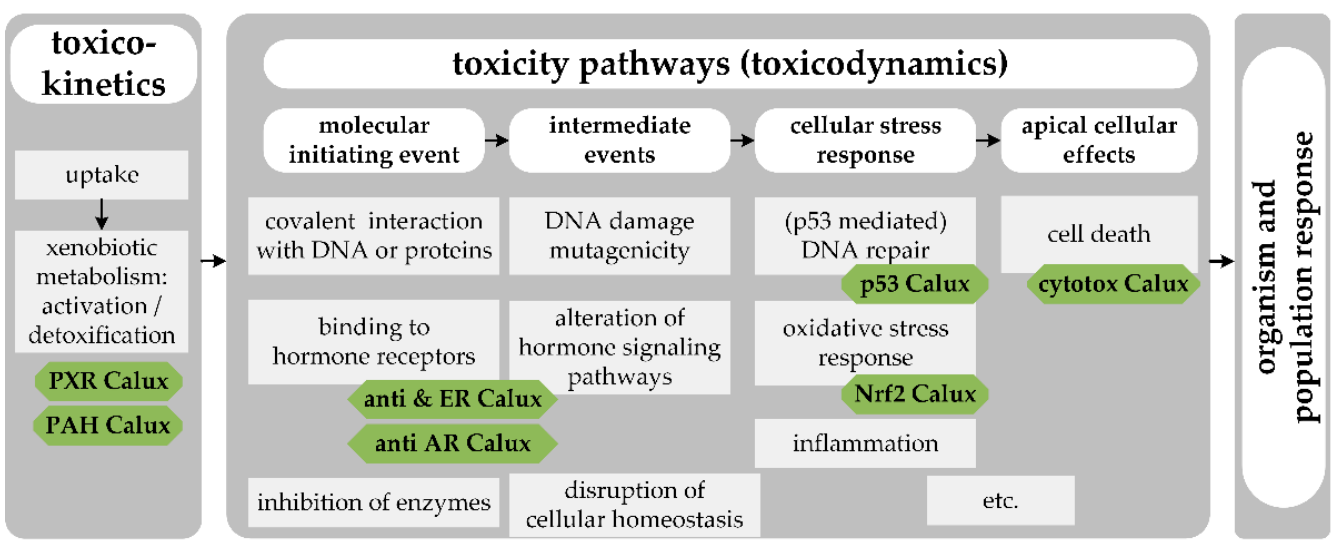

Figure 2. In vitro CALUX bioassay panel allocated to the corresponding events on the toxicity pathway (according to [14], modified).

Five of the nine modes of action investigated in this long-term monitoring were suggested for WWTP effluent monitoring in the joint NORMAN and Water Europe Position paper [25] by the NEREUS COST Action ES 1403. Additionally, genotoxicity and cytotoxicity were included, being amongst the first endpoints applied for water quality assessment [31]. Anti-estrogenicity was investigated as an additional hormone-mediated assay.

A summary of the applied CALUX bioassays covering the measured endpoints, reference compounds, and EBTs is given in Table 1. For quantification of the analyzed effect, the results of the CALUX bioassays and corresponding EBTs are provided as biological equivalents (BEQ) per liter sample related to reference compounds given in Table 1. BEQ were expressed as tributyltin acetate equivalent concentration (TBT-EQ) for cytotoxicity, $17 \beta$-estradiol equivalent concentration (EEQ) for estrogenicity, tamoxifen equivalent concentration (Tam-EQ) for anti-estrogenicity, flutamide equivalent concentration (Flu-EQ) for anti-androgenicity, curcumin equivalent concentration (Cur-EQ) for oxidative stress response, cyclo-phosphamide equivalent concentration (CPA-EQ) for genotoxicity with metabolic activation S9, actinomycin equivalent concentration (ACT-EQ) for genotoxicity without metabolic activation S9, benzo[a]pyrene equivalent concentration (B[a]P-EQ) for toxic PAH and nicardipine equivalent concentration (Nic-EQ) for xenobiotic sensing with PXR CALUX.

An individual limit of quantification (LOQ) is determined for every single analysis. Genotoxicity was analyzed with and without the addition of S9 for metabolic activation. Different results with S9 addition elucidate a metabolization or detoxification of ingredients [13] and helps differentiate between directly and indirectly acting genotoxic compounds.

Not each endpoint was targeted in every sample. While the hormone-mediated MOA $\mathrm{ER} \alpha$ (in short, ER) and anti-AR CALUX were measured in all samples, the remaining six endpoints were analyzed alternately according to the frequency depicted in Table S2. 
Table 1. Information on the CALUX in vitro bioassay panel and frequency of analysis.

\begin{tabular}{|c|c|c|c|c|}
\hline Bioassay & Effect & $\begin{array}{l}\text { Measured Endpoint or } \\
\text { Molecular Target }\end{array}$ & Reference Compound & $\mathrm{EBT}^{* * *}[\mathrm{BEQ}]$ \\
\hline Cytotox & Cytotoxicity & $\begin{array}{l}\text { Repression of constitutive } \\
\text { transcriptional activation }\end{array}$ & Tributyltin acetate & - \\
\hline $\mathrm{ER} \alpha) *$ & Estrogenicity & $\begin{array}{l}\text { Estrogen receptor } \alpha \text {-mediated } \\
\text { signalling }\end{array}$ & $17 \beta$-Estradiol & $0.1 \mathrm{ng} / \mathrm{L}$ \\
\hline anti-ER $\alpha$ & Anti-estrogenicity & $\begin{array}{l}\text { Repression of estrogen } \\
\text { receptor } \alpha \text {-mediated signalling }\end{array}$ & Tamoxifen & not available \\
\hline anti-AR )* & Anti-androgenicity & $\begin{array}{l}\text { Repression of androgen } \\
\text { receptor activation }\end{array}$ & Flutamide & $14 \mu \mathrm{g} / \mathrm{L}$ \\
\hline $\mathrm{Nrf2}) *$ & $\begin{array}{l}\text { Oxidative stress } \\
\text { response }\end{array}$ & Activation of the Nrf2 pathway & Curcumin & $10 \mu \mathrm{g} / \mathrm{L}$ \\
\hline p53 + S9 & $\begin{array}{c}\text { Genotoxicity response } \\
+ \text { S9 }\end{array}$ & $\begin{array}{l}\text { p53-dependent pathway } \\
\text { activation with S9 }\end{array}$ & Cyclo-phosphamide & - \\
\hline p53 - S9 & $\begin{array}{c}\text { Genotoxicity response } \\
\text {-S9 }\end{array}$ & $\begin{array}{l}\text { p53-dependent pathway } \\
\text { activation without S9 }\end{array}$ & Actinomycin & - \\
\hline PAH ${ }^{*} *$ & $\begin{array}{l}\text { Toxic PAH-xenobiotics } \\
\text { metabolism }\end{array}$ & $\begin{array}{l}\text { Aryl-hydrocarbon receptor } \\
\text { activation }\end{array}$ & Benzo[a]pyrene & $6.2 \mathrm{ng} / \mathrm{L}$ \\
\hline PXR )* & $\begin{array}{l}\text { Xenobiotic metabolism } \\
\text { and sensing }\end{array}$ & $\begin{array}{l}\text { Activation of pregnane } X \\
\text { receptor }\end{array}$ & Nicardipine & $3 \mu \mathrm{g} / \mathrm{L}$ \\
\hline
\end{tabular}

)* bioassays suggested in the joint position paper by NORMAN and Water Europe [25]; for endpoints given in this paper, the lower EBT suggested was applied. )** EBTs linked to the MOA were retrieved from the literature [10,24].

\subsection{Data Interpretation}

If the BEQ was below the LOQ, half the LOQ was used as a result. This approach was applied in order to not exclude results $<$ LOQ from statistical analysis. Due to the sample-specific LOQs, the BEQ derived from results < LOQ can slightly deviate and, in some cases, give the impression of an increased signal along with the treatment steps.

\section{Results}

This paper presents long-term toxicological monitoring of a multibarrier treatment system with ozonation and granular activated carbon treatment under realistic conditions. The applied technologies were investigated with a panel of in vitro bioassays involving selected water-relevant MOA along the cellular toxicity pathway. Two approaches were employed to assess the suitability and the performance of the treatment technologies:

1. The BEQ decrease was determined for the various steps of the multibarrier system (CAS-OUT, $\mathrm{O}_{3}$-OUT, and GAC-OUT).

2. The BEQ were compared to currently discussed MOA-specific EBTs to identify the impact of advanced treatment.

Figure 3a gives an overview of the cytotoxic effects after conventional and advanced treatment. Figure $3 \mathrm{~b}$ demonstrates the TBT-equivalents for each sampling campaign. After conventional treatment, TBT-EQ ranged between 0.19 and $3.3 \mu \mathrm{g} / \mathrm{L}$, with a median of $0.64 \mu \mathrm{g}$ TBT-EQ/L. Cytotoxicity was below LOQ in seven out of sixteen samples (Table S3). In the rest of the samples, ozonation decreased the effect below LOQ, where it remained after the subsequent GAC treatment (Figure $3 b$ and Table S3). The median decline in cytotoxicity achieved $83 \%$ (Figure 4 ) already after the first step of the multibarrier treatment system. 


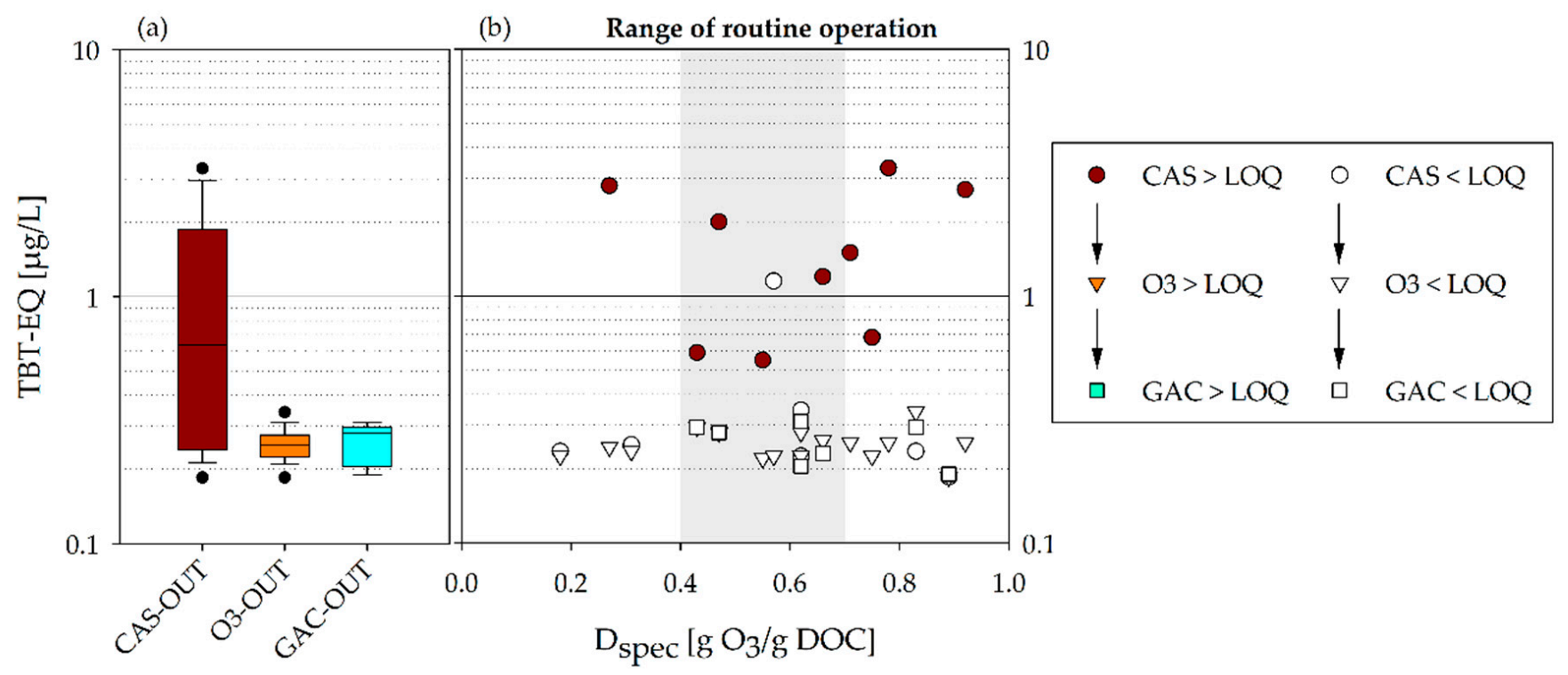

Figure 3. (a) Boxplot showing the range of tributyltin acetate equivalents over all campaigns along the multibarrier system; the box indicates the 25 th to 75 th percentile and the line within the box indicates the median. The whiskers show the 10th and the 90th percentiles and data points that lie outside these percentiles are plotted as dots. (b) TBT-EQ along the multibarrier system for each sampling campaign.

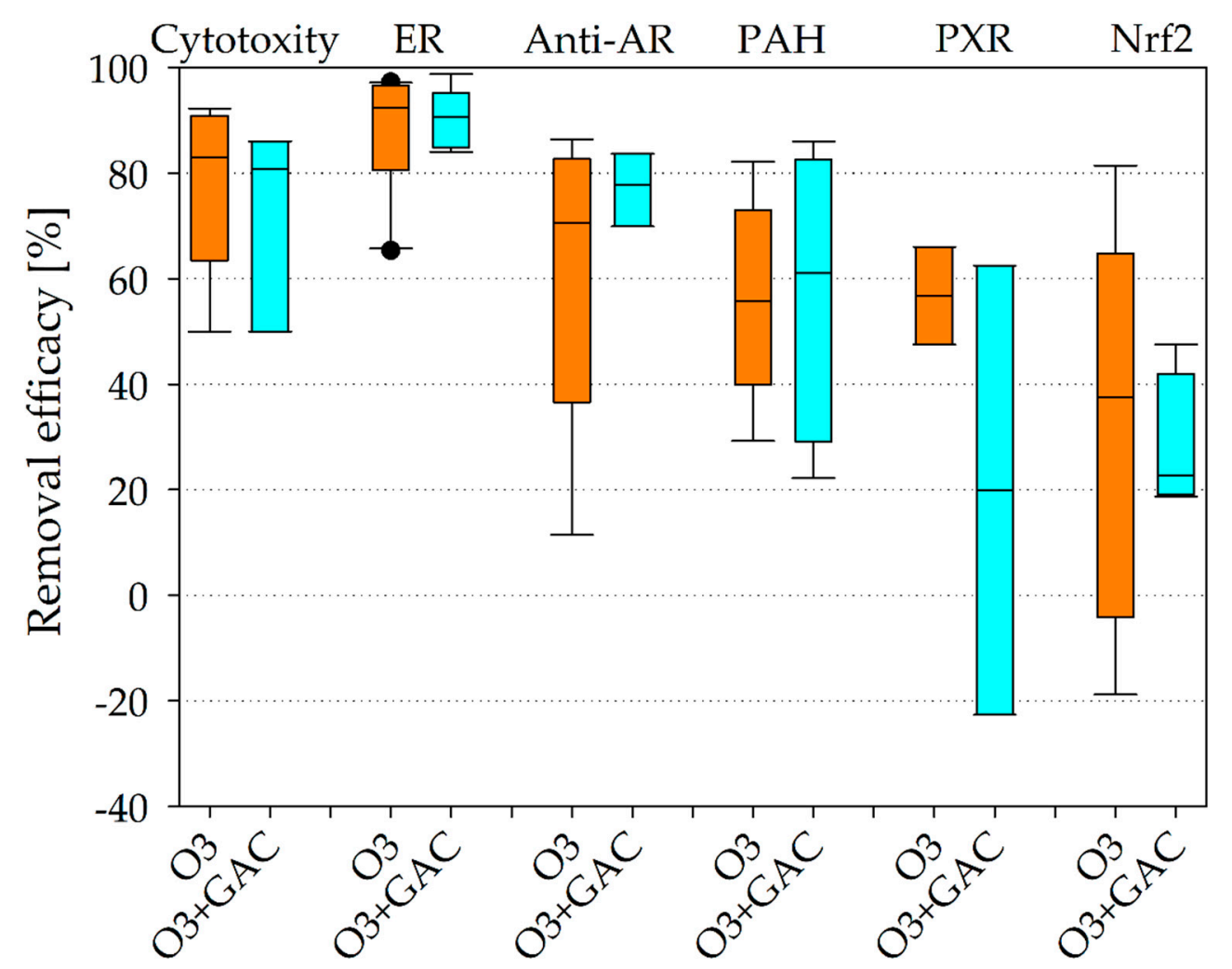

Figure 4. Boxplots showing the range of removal for the investigated MOA along the multibarrier treatment system over the one-year monitoring. 
In the effluent of the conventional WWTP, all but one sample were above the LOQ and EBT for estrogenic activity, respectively (Figure 5a,b, and Table S3). EEQ ranged from $0.15(0.09)-1.2 \mathrm{ng} / \mathrm{L}$ with a median at $0.42 \mathrm{ng} / \mathrm{L}$. Ozonation resulted in a substantial EEQ decline; half of the samples decreased $<\mathrm{LOQ}$, and only one out of 14 samples exceeded the EBT of $0.1 \mathrm{ng} E E Q / L$ by $0.02 \mathrm{ng} / \mathrm{L}(0.12 \mathrm{ng}$ EEQ/L). Similar results were obtained after GAC filtration with a single exceedance of the EBT (0.16 ng EEQ/L). Except for this sampling campaign, GAC-OUT results were in the same order of magnitude as in O3-OUT, impeding the determination of a significant further reduction.

A median decrease of $92 \%$ was achieved for the ozonation process $(n=13$, Figure 4$)$, only for the two lowest $\mathrm{D}_{\text {spec }}<0.3 \mathrm{~g} \mathrm{O}_{3} / \mathrm{g}$ DOC the EEQ reduction was below $70 \%$. Taking the smaller sample size for the GAC filter $(n=7)$ into account, the removal of the multibarrier system (O3 + GAC) was in the same range.

Anti-androgenicity was $<\mathrm{LOQ}$ in ten out of sixteen effluent samples of the conventional WWTP (Figure S1, Table S4). The EBT of $14 \mu \mathrm{g}$ Flu-EQ/L was exceeded twice (16 and $18 \mu \mathrm{g} / \mathrm{L}$ ). Even though ozonation resulted in a decrease below LOQ for the remaining six samples, the further removal is not evident in the median (Figure S1a); this is a result of the sample-specific LOQ, which were partly lower in CAS-OUT than in O3-OUT. Considering the single campaigns where anti-androgenic effects were detected in CAS-OUT (Figure S1b), however, the removal potential of the ozonation step becomes apparent. In GAC-OUT the effect remained $<L O Q$. Thus, none of the multibarrier effluent samples exceeded the EBT of $14 \mu \mathrm{g}$ Flu-EQ/L. The median anti-androgenicity removal in the ozonation and the multibarrier system was $72(\mathrm{n}=6)$ and $78 \%(\mathrm{n}=3$, Figure 4$)$, calculated with $\frac{1}{2}$ LOQ.

Anti-estrogenic effects were analyzed only twice, and it was $<$ LOQ during the first screening. The second screening gave $0.51 \mu \mathrm{g}$ Tam-EQ/L in the effluent of the conventional treatment, and after ozonation $\left(0.7 \mathrm{~g} \mathrm{O}_{3} / \mathrm{g}\right.$ DOC $)$ and GAC-treatment the effect decreased $<$ LOQ.

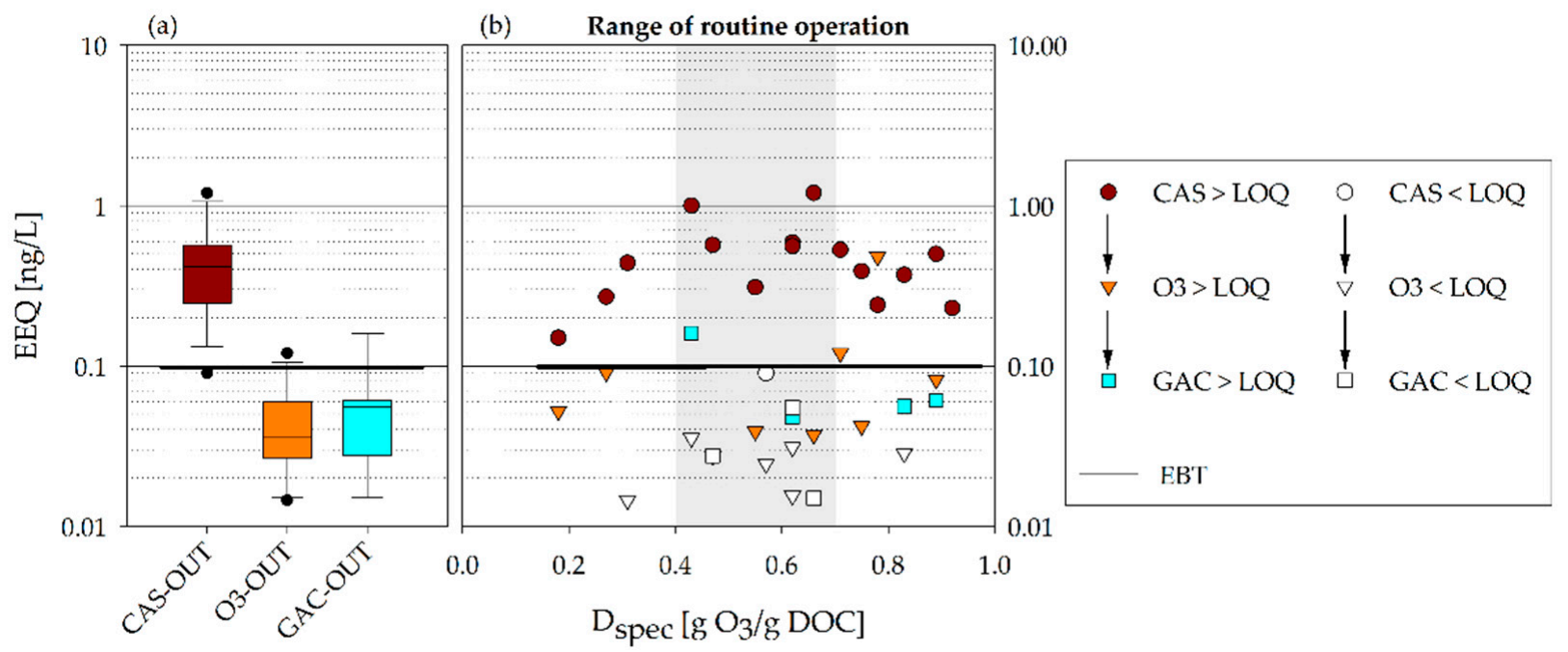

Figure 5. (a) Boxplot showing the range of $17 \beta$ estradiol equivalents over all campaigns along the multibarrier system; (b) EEQ along the multibarrier system for each sampling campaign.

In the effluent of the conventional WWTP, the benzo[a]pyrene equivalents ranged between 100 and $270 \mathrm{ng} / \mathrm{L}$, with a median at $145 \mathrm{ng} / \mathrm{L}$. The ozonation resulted in a decrease of the B[a]P-EQ (Figure 6). Despite a median decline of 56-61\% (cf. Figure 4), Figure 6 demonstrates the constant exceedance of the proposed and here applied EBT. This EBT is mainly based of B[a]P, while many kinds of different PAHs can occur in such complex mixtures. 


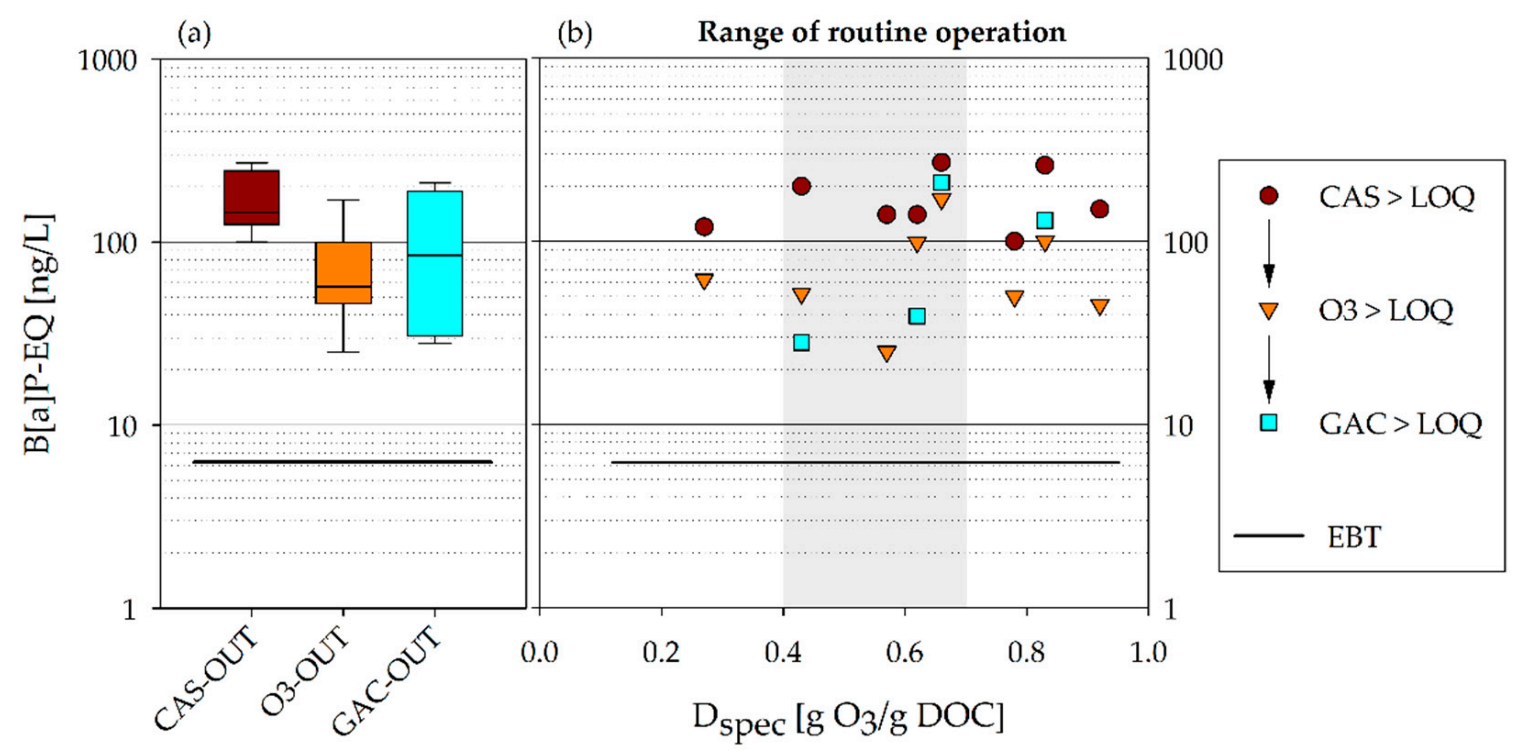

Figure 6. (a) Boxplot showing the range of benzo[a]pyrene equivalents over all campaigns along the multibarrier system; (b) B[a]P-EQ along the multibarrier system for each sampling campaign.

Results on xenobiotic sensing are depicted in Figure S2. For one of the three analyzed campaigns, BEQ were below the LOQ for all three sampling sites. The remaining two campaigns delivered a removal of 48 and $66 \%$ during ozonation. For the GAC filter, however, contradictory results were obtained. While an increase of the PXR activity was observed for the first sampling that was done at approx. 1000 bed volumes (BV) treated, a further removal after ozonation occurred in a sampling campaign after one year of operation at approx. 33,100 BV.

Four out of 13 analyzed samples of CAS-OUT were below the LOQ (Table S4). Despite a reduction during advanced treatment, the samples still had the potency to trigger oxidative stress response mechanisms. Due to the varying LOQ for the different treatment stages, the signal after ozonation and after GAC was reduced below LOQ only once (Table S4). An increase was determined for the ozonation in two sampling campaigns, but GAC resulted in an overall decrease. All analyzed samples were above the EBT of 10 ng Cur-EQ/L (Figure S3).

The genotoxic activity was below the LOQ both with $(n=5)$ and without the addition of the metabolic activation mix S9 $(n=3)$.

\section{Discussion}

The long-term toxicological monitoring offered a valuable opportunity to encounter realistic operating conditions, including fluctuations in wastewater quantity and quality, which can impact conventional and advanced treatment.

Nevertheless, most ozonation plants apply flow-proportional dose control due to enhanced efforts required for water quality-related operation. Concerning the process stability of conventional biological treatment, insufficient nitratation within the two-step nitrification process can lead to nitrite occurrence. Nitrite has a stochiometric ozone consumption of $3.43 \mathrm{mg} \mathrm{O} / 3 / \mathrm{mg} \mathrm{NO}_{2}-\mathrm{N}$ and decreases the effective $\mathrm{D}_{\text {spec }}$ if nitrite compensation is not implemented in the process control strategy. A model calculation with a setpoint of $0.55 \mathrm{~g} \mathrm{O}_{3} / \mathrm{g}$ DOC and a DOC effluent concentration of $4.5 \mathrm{mg} / \mathrm{L}$ demonstrates that $0.2 \mathrm{mg}$ $\mathrm{NO}_{2}-\mathrm{N} / \mathrm{L}$ decreases the effective $\mathrm{D}_{\text {spec }}$ to $0.4 \mathrm{~g} \mathrm{O}_{3} / \mathrm{g}$ DOC, which equals a decrease of $28 \%$. Taking fluctuations in the effluent quality (nitrite or DOC) into account, the effective $\mathrm{D}_{\text {spec }}$ can readily vary between 0.4 and $0.7 \mathrm{~g} \mathrm{O}_{3} / \mathrm{g}$ DOC with flow-proportional control.

Due to the potential variations, Figures 3, 5 and 6 in the results chapter indicate a $\mathrm{D}_{\text {spec }}$ of 0.4 to $0.7 \mathrm{~g} \mathrm{O}_{3} / \mathrm{g}$ DOC as the range of routine operation. This range coincides quite well with the recommended $\mathrm{D}_{\text {spec }}$ of 0.4 to $0.6 \mathrm{~g} \mathrm{O}_{3} / \mathrm{g}$ DOC for CEC abatement from 
tertiary treated wastewater [32], and with the $\mathrm{D}_{\text {spec }}$ of $0.55 \mathrm{~g} \mathrm{O}_{3} / \mathrm{g}$ DOC applied at the first full-scale WWTP upgraded with ozonation at Neugut, Switzerland [33].

The sampling campaigns with lower specific ozone doses simulate nitrite occurrence and the lack of adequate process control in order to assess the impact of low ozone doses on the investigated MOA. Apart from the estrogenic activity that revealed a signal reduction $<70 \%$ for the two campaigns with a $\mathrm{D}_{\text {spec }}<0.3 \mathrm{~g} \mathrm{O}_{3} / \mathrm{g}$ DOC, no clear correlation with the tested doses (0.18-0.92 $\mathrm{g} \mathrm{O}_{3} / \mathrm{g}$ DOC) and the range of routine operation, respectively, could be determined.

After the conventional treatment, cytotoxicity was in the range representative for other Austrian CAS-plants with full nitrification and denitrification [34]. The advanced treatment proved beneficial for baseline toxicity removal, confirming the suitability of the multibarrier system. Since transformation products formed during ozonation are more hydrophilic, they are less cytotoxic, but still contribute to mixture effects [35]. Biodegradation during biologically activated GAC theoretically offers the potential to reduce these effects, but in the present study it was not possible to prove this due to the non-detects after ozonation. A significant reduction after ozonation was also determined in a study on three German WWTPs [36]. In addition, they also revealed the effect reduction potential of biological posttreatment with a fluidized bed reactor. Even though GAC, applied in the present study, differs from the fluidized bed reactor, both systems represent biological posttreatment processes. Thus, it is a strong indication for an additional benefit of GAC and the strength of the multibarrier approach.

As cytotoxicity is a non-specific toxicity endpoint that provides an estimate of the overall toxic burden in a mixture, it is considered important to be investigated [37].

The range of $17 \beta$ estradiol equivalents (EEQs) observed in the effluent of the conventional treatment was in accordance with nine Austrian WWTPs [34] and can be considered as representative for CAS-plants operated according to the EU requirements for eutrophication sensitive areas [5] applying biological nitrogen removal (tertiary treatment). Biological nitrogen removal can only be achieved at low-loaded WWTPs with high solids retention time, a parameter that correlates well with estrogenicity removal [38]. This correlation is partly reflected by data for ER $\alpha$ CALUX determined in the effluent of 12 European WWTPs along the Danube River [29]. High-loaded WWTP with only secondary treatment (carbonaceous biological oxygen demand removal, but no biological nitrogen removal) are mostly characterized by higher effluent EEQ compared to tertiary treatment.

According to NEREUS [39], an average decrease of estrogenic activity by approx. one order of magnitude was observed during conventional treatment. The results of this paper showed that an average decrease by another order of magnitude could be accomplished with advanced treatment. A significant EEQ decrease by ozonation was also observed during other full-scale studies $[36,40,41]$. The reduction of the EEQ that occurred during ozonation can be attributed to the high reactivity of high-potency estrogens with ozone [42]. This conclusion is permitted since estrogenicity is one of the endpoints with a high overlapping of the biological and the chemical BEQ; the latter are calculated by summing up the products of the chemical concentration and the corresponding relative effect potencies $[19,43]$. Even though estrogenicity decline could not be quantified for GAC, a good EEQ removal potential can be assumed based on a review on toxicity removal by advanced wastewater treatment with ozonation and activated carbon treatment [28]. According to the published data, the median reduction for AC treatment amounted to 75\%.

Receptor-mediated estrogenicity is one of the most relevant MOA for endocrine disrupting compounds [19]. Consequently, the significant reduction (median removal > 90\%) can be considered a substantial benefit of the multibarrier system.

Studies on the removal of endocrine effects during advanced treatment put more focus on agonistic activity, even though pharmaceuticals like diclofenac belong to the group of hormone receptor antagonists [28]. While the difference was less pronounced for the androgenic receptor (eleven vs. nine studies), 22 studies were done on estrogenicity and seven on anti-estrogenicity. Three of them reported tamoxifen equivalent concentra- 
tions < LOQ. Similar results were obtained in the presented study with two samplings covering anti-estrogenicity. Anti-estrogenicity was only measured once in the effluent of the conventional treatment, and it decreased to $<$ LOQ after ozonation. This observed decline contradicts four studies reporting an increase after ozonation, which appeared to correlate with an increasing ozone dose [28]. Contrary to this, an unclear elimination pattern was found on a full-scale ozonation plant, i.e., independent of the ozone dose, formation and elimination were observed during six monitoring campaigns [40].

The anti-androgenicity was in the lower range measured for effluents of other conventional biological WWTPs in Austria [34] and in the Danube River Basin [29]. Despite the calculation with $\frac{1}{2}$ LOQ due to $100 \%$ non-detects in the effluent of the advanced treatment stages, a clear removal pattern for anti-androgenicity in ozonation and the multibarrier system was detected during the monitoring campaign (69 and 77\%, respectively). The removal was in line with published data for ozonation (81.5\%) and activated carbon (62.4\%) [28]. In contrast, a current full-scale study with ozonation did not identify a clear removal pattern [40].

The PAH-CALUX belongs to the specific toxicity endpoints which induce xenobiotic metabolism. This endpoint is characterized by a high frequency of occurrence in municipal wastewater [28]. Positive signals for PAH activity were detected in all WWTP effluents investigated in Austria $(n=9)$ and in the Danube River Basin $(n=12)[29,34]$. The BEQ in the present paper were in a similar concentration range, thus, representative for urban WWTPs. The removal efficiency for B[a]P-EQ of approx. $60 \%$ during advanced treatment was slightly lower than published values of 79 and $84 \%$ for ozonation and activated carbon, respectively, [28]. After all, the multibarrier system could not reduce the activity below the discussed EBT of $6.2 \mathrm{ng} \mathrm{B[a]P-EQ/L.}$

In addition to the PAH CALUX, the PXR CALUX is another bioassay targeting the induction of xenobiotic metabolism. Since the pregnane $X$ receptor is activated by different types of chemically nonrelated compounds, comprising environmental pollutants and pharmaceuticals, this bioassay can be applied for xenobiotic sensing [44]. PAH and PXR activity belonged to the most frequently detected endpoints in the Joint Danube Survey [29], and the Nic-EQ in CAS-OUT were within the same range as the investigated WWTPs. In literature, a median removal of $\geq 78 \%$ was reported for combined ozonation-GAC treatment [17]. In the present study, two contrary results were obtained. In a first campaign, $66 \%$ were achieved by ozonation, but a negative removal was determined for the multibarrier system after GAC treatment at a low BV of around 1000. During a campaign at a later stage (33,098 BV), the removal efficiency increased from $48 \%$ (after ozonation) to $63 \%$. Reasons for these divergent results are not clear; on the one hand, the adsorption capacity of the activated carbon around $1000 \mathrm{BV}$ is still high; on the other hand, the biological activation of the filter can be assumed to be in the start-up phase. Both processes (adsorption and biodegradation) occur in parallel, with a share depending on the treated wastewater, the BV treated, and the substance characteristics. Usually, it is not possible to easily differentiate between these two processes in a GAC filter [33]. However, the data set is too small to conclude the effect of biological activity in the filter on the PXR activity, and further investigations would be needed.

In the monitoring studies in Austria and the Danube river basin [29,34], oxidative stress (Nrf2 CALUX ${ }^{\circledR}$ ) was identified in 18 out of 21 conventional WWTP effluent samples. The numbers were in the same order of magnitude as in the presented long-term study, confirming the consistent exceedance of EBTs. For the ozonation process, a median removal of $46 \%$ was determined. Additional reduction in the GAC step was observed during three of five sampling campaigns. In contrast, the other campaigns revealed an increase in response and no change to the ozonation. Literature results showed $63 \%$ removal for an ozonation plant and $>25$ to $>95 \%$ (median of $44 \%$ ) for a combined O3 and GAC treatment [28].

Oxidative stress represents a rather general cellular stress response that can often be detected before cytotoxic effects [37,45]. This is consistent with the present results, with 
cytotoxic effects more often $<$ LOQ, even before advanced treatment. Like biological treatment, ozonation processes lead to transformation rather than mineralization, which causes the weaker decline observed for oxidative stress response compared to other investigated endpoints, such as estrogenicity or anti-androgenicity.

The results of the p53 CALUX assay agreed with the outcomes of the Ames test with the standard bacterial strains TA98 and TA100 [46]. Both bacterial strains consistently gave negative results with and without $\mathrm{S} 9$ addition in three sampling campaigns.

Figure 4 , as a summarizing graph, gives an overview of the removal range for the investigated MOA considering all sampling campaigns irrespective of the specific ozone doses. Genotoxicity and anti-estrogenicity were not integrated due to their lack of occurrence. A median removal of $>80 \%$ was achieved only for estrogenicity and cytotoxicity. Estrogenicity was the endpoint with the lowest variations. After ozonation, the 25th percentile removal was $>80 \%$, and after GAC the minimum removal determined was $84 \%$. A removal $<70 \%$ can be related to $\mathrm{D}_{\text {spec }}<0.3 \mathrm{~g} \mathrm{O}_{3} / \mathrm{g}$ DOC, though. Cytotoxicity seemed to have higher variations, but all results were $<$ LOQ after ozonation and activated carbon treatment, respectively. Thus, the calculated removal based on $\frac{1}{2}$ LOQ can deviate. The same is valid for anti-androgenicity with $100 \%$ of the data $<$ LOQ after advanced treatment.

While the evaluation of the BEQ decrease represents the first approach to assess the suitability and performance of the treatment system, the second approach dealt with the comparison of the BEQ with currently discussed MOA-specific EBT (cf. Figures 3b, 5b, $6 b$ and S1b-S3b). Table 2 shows the $\mathrm{n}$-fold exceedance of the median relative to currently discussed EBT values according to the concept suggested by [29].

Table 2. n-fold EBT-exceedance of the median BEQ for all sampling campaigns. The color code refers to the degree of exceedance.

\begin{tabular}{|c|c|c|c|c|c|c|c|}
\hline \multirow{2}{*}{ Bioassay } & \multirow{2}{*}{ EBT } & \multirow{2}{*}{ CAS-OUT } & \multirow{2}{*}{ O3-OUT } & \multirow{2}{*}{ GAC-OUT } & CAS-OUT & O3-OUT & GAC-OUT \\
\hline & & & & & \multicolumn{3}{|c|}{ Frequency of Exceedance [n/All] } \\
\hline $\mathrm{ER} \alpha$ & 0.1 & 4 & 0.4 & 0.6 & $14 / 16$ & $1 / 14$ & $1 / 7$ \\
\hline anti-AR & 14 & 0.1 & 0.2 & 0.2 & $2 / 16$ & $0 / 16$ & $0 / 7$ \\
\hline Nrf2 & 10 & 9 & 7 & 9 & $13 / 13$ & $13 / 13$ & $5 / 5$ \\
\hline PAH & 6.2 & 23 & 9 & 14 & $8 / 8$ & $8 / 8$ & $4 / 4$ \\
\hline PXR & 3 & 13 & 6 & 5 & $3 / 3$ & $2 / 3$ & $2 / 2$ \\
\hline \multicolumn{2}{|c|}{ BEQ/EBT $<1$} & $1 \leq \mathrm{BEQ} / \mathrm{EBT}<3$ & \multicolumn{2}{|c|}{$3 \leq \mathrm{BEQ} / \mathrm{EBT}<10$} & $10 \leq \mathrm{BEQ} /$ & 100 & $\mathrm{BT}>100$ \\
\hline
\end{tabular}

A typical pattern for the degree of exceedance could be observed by a decline in response from left to right, following the treatment train. An increase in treatment steps usually resulted in improved water quality even if the BEQ was still exceeded by up to ninefold for selected endpoints other than hormone-mediated endpoints. PAH activity, however, seemed to increase again after GAC treatment, which is most probably due to the smaller data set for GAC than for O3 (four versus eight data points).

Bioassay responses of more than 100 times the EBT are indicative for high risk, but appropriate measures can be taken if chemicals causing the effects are known [24]. Linking in vitro effects and organic micropollutants detected in surface water with mixturetoxicity modeling was only applicable for a limited number of endpoints, among them estrogenic effects [43]. The $>100$-fold exceedance in WWTP influent for estrogenicity is significantly reduced by conventional wastewater treatment [39], and can be further reduced by advanced treatment.

The amount of CEC currently in use is high, and CEC abatement by conventional treatment is limited. Thus, the additional barrier of advanced treatment technologies should be considered in the future, even if bioassay responses after advanced treatment with a multibarrier system comprising $\mathrm{O}_{3}$ and GAC were still elevated for endpoints like PAH-like activities and oxidative stress activities.

Bioassays targeting xenobiotic metabolism and repair and defense mechanisms are sensitive tools to detect the occurrence of CEC, since effects can often be identified at concentrations lower than those resulting in cell death or damage [43], as confirmed by 
literature [31] and the present results. In addition, the activation of metabolism as a toxicokinetic process cannot be considered an adverse effect per se, but rather an indication of the presence of bioactive chemicals $[10,28]$. Thus, wastewater samples can be regarded as subject to the induction of specific endpoints like the aryl hydrocarbon receptor (AhR) targeted by the PAH CALUX and the pregnane X receptor (PXR) as observed in the long-term monitoring. This is not necessarily linked to an adverse outcome, especially when considering the high level of treatment in the multibarrier system and the overall decreasing response trend. Moreover, a slight exceedance of EBT in one or two bioassays is not inherently linked to increased ecological risk [24]. After all, not only WWTP discharges, as point sources, but also diffuse sources, e.g., from agriculture, show effects [47].

\section{Conclusions}

The following summarizing conclusions can be drawn from the application of toxicological long-term monitoring of an advanced wastewater treatment plant with a battery of in vitro bioassays covering various endpoints along the toxicity pathway:

- Toxicological long-term monitoring delivered a valid basis for assessing the applicability and the performance of a multibarrier system for an advanced treatment.

- The combination of the two approaches applied in the present study, namely the quantification of BEQ decline and comparison of BEQ with currently discussed EBTs, represented a solid means of assessing the final effluent quality of the multibarrier system combining ozonation and granular activated carbon treatment.

- Despite natural variations in wastewater characteristics and other factors influencing CAS treatment efficiency over the 13-month monitoring, the overall removal pattern for various modes of action covering endpoints along the toxicity pathway revealed a decrease in BEQ.

- Even though the positive effect of ozonation resulting in signals below LOQ for some MOA impeded the assessment of the GAC treatment, a combination of O3 and GAC is strongly recommended for advanced treatment in order to follow the multibarrier approach and guarantee a high level of treatment.

- Since the presented toxicological results did not reveal significant differences within the recommended ozone dose range of $0.4-0.7 \mathrm{~g} \mathrm{O} / \mathrm{g}$ DOC, it can be concluded that potential toxicological requirements should not be limiting for the implementation and operation of multibarrier systems for CEC abatement.

- Even though measures like implementing advanced treatment at WWTPs do not result in a complete removal, advanced treatment represents a relevant step in reducing the toxicological burden for the aquatic environment.

- Effect-based bioassays with their linked EBTs should be used as treatment goals and quality criteria for design, operation and the evaluation of advanced wastewater treatment.

Supplementary Materials: The following are available online at https:/ /www.mdpi.com/article/10 .3390/w13223245/s1, Table S1: Frequency of sampling for each sampling point, sorted by specific ozone dose. Bed volumes (BV) are only given for routine monitoring campaigns; Table S2: Frequency of analysis for the applied bioassays at the sampling points including method references; Table S3: BEQs for cytotoxicity, estrogenicity and toxic PAH-like activities along the multibarrier system for each sampling campaign; Table S4: BEQs for anti-androgenicity (Anti-AR), xenobiotic sensing (PXR) and oxidative stress (Nf2) response along the multibarrier system for each sampling campaign; Figure S1: (a) Boxplots showing the range of flutamide equivalents over all campaigns along the multibarrier system; (b) Flu-EQ along the multibarrier system for each sampling campaign; Figure S2: (a) Boxplots showing the range of nicardipine equivalents over all campaigns along the multibarrier system; (b) Nic-EQ along the multibarrier system for each sampling campaign; Figure S3: (a) Boxplots showing the range of curcumin equivalents over all campaigns along the multibarrier system; (b) CurEQ along the multibarrier system for each sampling campaign; Figure S4: The range of removal for the investigated MOA after ozonation over the one-year monitoring; Figure S5: The range of 
removal for the investigated MOA after the multibarrier system (ozonation and GAC) over the one-year monitoring.

Author Contributions: Sample extraction, data curation, writing-original draft preparation: L.T.P.; conceptualization, supervision, writing, review and editing: H.S.; plant setup, plant supervision and sampling: D.R. \& S.W.; chemical analysis and supervision of laboratory work: E.S.; project supervision, review: J.K.; bioassay selection, review and editing: P.A.B.; project administration, review and supervision: N.K. All authors have read and agreed to the published version of the manuscript.

Funding: This research was funded by the Austrian Federal Ministry of Agriculture, Regions and Tourism, grant number B601389, and by the Federal Government of Burgenland, grant number A5/WWK.WPO200-10034-2-2016.

Acknowledgments: Acknowledgments are given to the NEREUS COST Action ES1403 for funding the short-term scientific mission for the training at BioDetection Systems bv. Special thanks are also dedicated to the treatment plant operators of the municipality Frauenkirchen for their effort in operating a novel treatment system. The authors also acknowledge Open Access Funding by TU Wien.

Conflicts of Interest: The authors declare no conflict of interest.

\section{References}

1. Escher, B.I.; Stapleton, H.M.; Schymanski, E.L. Tracking complex mixtures of chemicals in our changing environment. Science 2020, 367, 388-392. [CrossRef]

2. Fatta-Kassinos, D.; Bester, K.; Kümmerer, K. Xenobiotics in the Urban Water Cycle, 1st ed.; Springer: Dordrecht, The Netherlands; Heidelberg, Germany; London, UK; New York, NY, USA, 2010.

3. Krzeminski, P.; Tomei, M.C.; Karaolia, P.; Langenhoff, A.; Almeida, C.M.R.; Felis, E.; Gritten, F.; Andersen, H.R.; Fernandes, T.; Manaia, C.M.; et al. Performance of secondary wastewater treatment methods for the removal of contaminants of emerging concern implicated in crop uptake and antibiotic resistance spread: A review. Sci. Total Environ. 2019, 648, 1052-1081. [CrossRef] [PubMed]

4. Directive 2000/60/EC. Directive of the European Parliament and of the Council of 23 October 2000 Establishing a Framework for the Community Action in the Field of Water Policy. OJ L 327, 22 December 2000.

5. Directive 91/271/EEC. Directive concerning Urban Waste Water Treatment (UWWTD). OJ L 135, 30 May 1991.

6. Commission Implementing Decision (EU) 2015/495. Commission Implementing Decision establishing a Watch List of Substances for Union-Wide Monitoring in the Field of Water Policy Pursuant to Directive 2008/105/EC of the European Parliament and of the Council. OJ L 78, 2015.

7. Commission Implementing Decision (EU) 2018/840. Commission Implementing Decision of 5 June 2018 Establishing a Watch List of Substances for Union-Wide Monitoring in the Field of Water Policy Pursuant to Directive 2008/105/EC of the European Parliament and of the Council and Repealing Commission Implementing Decision (EU) 2015/495 (Notified under Document C(29018) 3362). OJ L 141, 7 June 2018.

8. Directive 2008/105/EC. Directive of the European Parliament and of the Council of 16 December 2008 on Environmental Quality Standards in the Field of Water Policy, Amending and Subsequently Repealing Council Directives 82/176/EEC, 83/513/EEC, 84/156/EEC, 84/491/EEC, 86/280/EEC and Amending Directive 2000/60/EC of the European Parliament and of the Council. OJ L 348, 24 December 2008.

9. Directive 2013/39/EU. Directive of the European Parliament and of the Council of 12 August 2013 Amending Directives 2000/60/EC and 2008/105/EC as Regards Priority Substances in the Field of Water Policy. OJ L 226, 24 August 2013.

10. Escher, B.I.; Aït-Aïssa, S.; Behnisch, P.A.; Brack, W.; Brion, F.; Brouwer, A.; Buchinger, S.; Crawford, S.E.; Du Pasquier, D.; Hamers, T; et al. Effect-based trigger values for in vitro and in vivo bioassays performed on surface water extracts supporting the environmental quality standards (EQS) of the European Water Framework Directive. Sci. Total Environ. 2018, 628-629, 748-765. [CrossRef] [PubMed]

11. Eggen, R.I.L.; Hollender, J.; Joss, A.; Schärer, M.; Stamm, C. Reducing the Discharge of Micropollutants in the Aquatic Environment: The Benefits of Upgrading Wastewater Treatment Plants. Environ. Sci. Technol. 2014, 48, 7683-7689. [CrossRef] [PubMed]

12. Connon, R.E.; Geist, J.; Werner, I. Effect-Based Tools for Monitoring and Predicting the Ecotoxicological Effects of Chemicals in the Aquatic Environment. Sensors 2012, 12, 12741-12771. [CrossRef]

13. Escher, B.I.; Leusch, F.D.L. Bioanalytical Tools in Water Quality Assessment; IWA Publishing: London, UK, 2012.

14. Neale, P.A.; Altenburger, R.; Aït-Aïssa, S.; Brion, F.; Busch, W.; de Aragão Umbuzeiro, G.; Denison, M.S.; Du Pasquier, D.; Hilscherová, K.; Hollert, H.; et al. Development of a bioanalytical test battery for water quality monitoring: Fingerprinting identified micropollutants and their contribution to effects in surface water. Water Res. 2017, 123, 734-750. [CrossRef]

15. Altenburger, R.; Ait-Aissa, S.; Antczak, P.; Backhaus, T.; Barceló, D.; Seiler, T.-B.; Brion, F.; Busch, W.; Chipman, K.; de Alda, M.L.; et al. Future water quality monitoring-Adapting tools to deal with mixtures of pollutants in water resource management. Sci. Total Environ. 2015, 512-513, 540-551. [CrossRef] 
16. Brack, W.; Ait-Aissa, S.; Burgess, R.M.; Busch, W.; Creusot, N.; Di Paolo, C.; Escher, B.I.; Mark Hewitt, L.; Hilscherova, K.; Hollender, J.; et al. Effect-directed analysis supporting monitoring of aquatic environments-An in-depth overview. Sci. Total Environ. 2016, 544, 1073-1118. [CrossRef]

17. Escher, B.I.; Allinson, M.; Altenburger, R.; Bain, P.A.; Balaguer, P.; Busch, W.; Crago, J.; Denslow, N.D.; Dopp, E.; Hilscherova, K.; et al. Benchmarking Organic Micropollutants in Wastewater, Recycled Water and Drinking Water with In Vitro Bioassays. Environ. Sci. Technol. 2014, 48, 1940-1956. [CrossRef]

18. Könemann, S.; Kase, R.; Simon, E.; Swart, K.; Buchinger, S.; Schlüsener, M.; Hollert, H.; Escher, B.I.; Werner, I.; Aït-Ä̈ssa, S.; et al. Effect-based and chemical analytical methods to monitor estrogens under the European Water Framework Directive. TrAC Trends Anal. Chem. 2018, 102, 225-235. [CrossRef]

19. Kase, R.; Javurkova, B.; Simon, E.; Swart, K.; Buchinger, S.; Könemann, S.; Escher, B.I.; Carere, M.; Dulio, V.; Ait-Aissa, S.; et al. Screening and risk management solutions for steroidal estrogens in surface and wastewater. TrAC Trends Anal. Chem. 2018, 102, 343-358. [CrossRef]

20. Pop, C.-E.; Draga, S.; Măciucă, R.; Niță, R.; Crăciun, N.; Wolff, R. Bisphenol A Effects in Aqueous Environment on Lemna minor. Processes 2021, 9, 1512. [CrossRef]

21. Wernersson, A.S.; Carere, M.; Maggi, C.; Tusil, P.; Soldan, P.; James, A.; Sanchez, W.; Dulio, V.; Broeg, K.; Reifferscheid, G.; et al. The European technical report on aquatic effect-based monitoring tools under the water framework directive. Environ. Sci. Eur. 2015, 27, 1-11. [CrossRef]

22. Brack, W.; Dulio, V.; Ågerstrand, M.; Allan, I.; Altenburger, R.; Brinkmann, M.; Bunke, D.; Burgess, R.M.; Cousins, I.; Escher, B.I.; et al. Towards the review of the European Union Water Framework Directive: Recommendations for more efficient assessment and management of chemical contamination in European surface water resources. Sci. Total Environ. 2017, 576, 720-737. [CrossRef] [PubMed]

23. Escher, B.I.; Neale, P.A.; Leusch, F.D.L. Effect-based trigger values for in vitro bioassays: Reading across from existing water quality guideline values. Water Res. 2015, 81, 137-148. [CrossRef] [PubMed]

24. Van der Oost, R.; Sileno, G.; Suárez-Muñoz, M.; Nguyen, M.T.; Besselink, H.; Brouwer, A. SIMONI (Smart Integrated Monitoring) as a novel bioanalytical strategy for water quality assessment: Part I-Model design and effect-based trigger values. Environ. Toxicol. Chem. 2017, 36, 2385-2399. [CrossRef]

25. NORMAN Network; Water Europe. Contaminants of Emerging Concern in Urban Wastewater. Joint NORMAN and Water Europe Position Paper. 2019. Available online: https://www.normandata.eu/sites/default/files/files/Publications/Position\%20paper_ CECs\%20UWW_NORMAN_WE_2019_Final_20190910_public.pdf (accessed on 26 September 2021).

26. Kienle, C.; Kase, R.; Werner, I. Evaluation of bioassays and wastewater quality. In In Vitro and In Vivo Bioassays for the Performance Review in the Project "Strategy MicroPoll"; Swiss Centre for Applied Ecotoxicology, Eawag-EPFL: Duebendorf, Switzerland, 2011.

27. Bain, P.A.; Williams, M.; Kumar, A. Assessment of multiple hormonal activities in wastewater at different stages of treatment. Environ. Toxicol. Chem. 2014, 33, 2297-2307. [CrossRef]

28. Völker, J.; Stapf, M.; Miehe, U.; Wagner, M. Systematic Review of Toxicity Removal by Advanced Wastewater Treatment Technologies via Ozonation and Activated Carbon. Environ. Sci. Technol. 2019, 53, 7215-7233. [CrossRef]

29. Alygizakis, N.A.; Besselink, H.; Paulus, G.K.; Oswald, P.; Hornstra, L.M.; Oswaldova, M.; Medema, G.; Thomaidis, N.S.; Behnisch, P.A.; Slobodnik, J. Characterization of wastewater effluents in the Danube River Basin with chemical screening, in vitro bioassays and antibiotic resistant genes analysis. Environ. Int. 2019, 127, 420-429. [CrossRef]

30. Ankley, G.T.; Bennett, R.S.; Erickson, R.J.; Hoff, D.J.; Hornung, M.W.; Johnson, R.D.; Mount, D.R.; Nichols, J.W.; Russom, C.L.; Schmieder, P.K.; et al. Adverse outcome pathways: A conceptual framework to support ecotoxicology research and risk assessment. Environ. Toxicol. Chem. 2010, 29, 730-741. [CrossRef]

31. Escher, B.I.; Dutt, M.; Maylin, E.; Tang, J.Y.M.; Toze, S.; Wolf, C.R.; Lang, M. Water quality assessment using the AREc32 reporter gene assay indicative of the oxidative stress response pathway. J. Environ. Monit. 2012, 14, 2877-2885. [CrossRef] [PubMed]

32. Rizzo, L.; Malato, S.; Antakyali, D.; Beretsou, V.G.; Đolić, M.B.; Gernjak, W.; Heath, E.; Ivancev-Tumbas, I.; Karaolia, P.; Lado Ribeiro, A.R.; et al. Consolidated vs new advanced treatment methods for the removal of contaminants of emerging concern from urban wastewater. Sci. Total. Environ. 2019, 655, 986-1008. [CrossRef]

33. Bourgin, M.; Beck, B.; Boehler, M.; Borowska, E.; Fleiner, J.; Salhi, E.; Teichler, R.; von Gunten, U.; Siegrist, H.; McArdell, C.S. Evaluation of a full-scale wastewater treatment plant upgraded with ozonation and biological post-treatments: Abatement of micropollutants, formation of transformation products and oxidation by-products. Water Res. 2018, 129, 486-498. [CrossRef]

34. Braun, R.; Hartmann, C.; Kreuzinger, N.; Lenz, K.; Schaar, H.; Scheffknecht, C. Untersuchung von Abwässern und Gewässern auf Unterschiedliche Toxikologische Endpunkte; Bundesministerium für Landwirtschaft, Regionen und Tourismus Vienna: Vienna, Austria, 2021; p. 248.

35. Escher, B.I.; Fenner, K. Recent Advances in Environmental Risk Assessment of Transformation Products. Environ. Sci. Technol. 2011, 45, 3835-3847. [CrossRef]

36. Dopp, E.; Pannekens, H.; Gottschlich, A.; Schertzinger, G.; Gehrmann, L.; Kasper-Sonnenberg, M.; Richard, J.; Joswig, M.; Grummt, T.; Schmidt, T.C.; et al. Effect-based evaluation of ozone treatment for removal of micropollutants and their transformation products in waste water. J. Toxicol. Environ. Health Part A 2021, 84, 418-439. [CrossRef] [PubMed]

37. Neale, P.A.; O’Brien, J.W.; Glauch, L.; König, M.; Krauss, M.; Mueller, J.F.; Tscharke, B.; Escher, B.I. Wastewater treatment efficacy evaluated with in vitro bioassays. Water Res. X 2020, 9, 100072. [CrossRef] 
38. Clara, M.; Kreuzinger, N.; Strenn, B.; Gans, O.; Kroiss, H. The solids retention time-A suitable design paramter to evaluate the capacity of wastewater treatment plants to remove micropollutants. Water Res. 2005, 39, 97-106. [CrossRef] [PubMed]

39. NEREUS. Deliverable 13. White Paper on the existing knowledge with regard to wastewater and biological hazards. In NEREUS COST Action ES 1403; Deliverable of WG3; 2018; 20p, Available online: http:/ /www.nereus-cost.eu/wp-content/uploads/2019 /12/D13.pdf (accessed on 26 September 2021).

40. Wolf, Y.; Oster, S.; Shuliakevich, A.; Brückner, I.; Dolny, R.; Linnemann, V.; Pinnekamp, J.; Hollert, H.; Schiwy, S. Improvement of wastewater and water quality via a full-scale ozonation plant?-A comprehensive analysis of the endocrine potential using effect-based methods. Sci. Total Environ. 2022, 803, 149756. [CrossRef]

41. Escher, B.I.; Bramaz, N.; Ort, C. JEM Spotlight: Monitoring the treatment efficiency of a full scale ozonation on a sewage treatment plant with a mode-of-action based test battery. J. Environ. Monit. 2009, 11, 1836-1846. [CrossRef]

42. Huber, M.M.; Göbel, A.; Joss, A.; Hermann, N.; Löffler, D.; McArdell, C.S.; Ried, A.; Siegrist, H.R.; Ternes, T.A.; von Gunten, U. Oxidation of Pharmaceuticals during Ozonation of Municipal Wastewater Effluents: A Pilot Study. Environ. Sci. Technol. 2005, 39, 4290-4299. [CrossRef]

43. Neale, P.A.; Ait-Aissa, S.; Brack, W.; Creusot, N.; Denison, M.S.; Deutschmann, B.; Hilscherová, K.; Hollert, H.; Krauss, M.; Novák, J.; et al. Linking in Vitro Effects and Detected Organic Micropollutants in Surface Water Using Mixture-Toxicity Modeling. Environ. Sci. Technol. 2015, 49, 14614-14624. [CrossRef]

44. Lemaire, G.R.; Mnif, W.; Pascussi, J.-M.; Pillon, A.; Rabenoelina, F.; Fenet, H.l.N.; Gomez, E.; Casellas, C.; Nicolas, J.-C.; Cavaillès, V.; et al. Identification of New Human Pregnane X Receptor Ligands among Pesticides Using a Stable Reporter Cell System. Toxicol. Sci. 2006, 91, 501-509. [CrossRef] [PubMed]

45. König, M.; Escher, B.I.; Neale, P.A.; Krauss, M.; Hilscherová, K.; Novák, J.; Teodorović, I.; Schulze, T.; Seidensticker, S.; Kamal Hashmi, M.A.; et al. Impact of untreated wastewater on a major European river evaluated with a combination of in vitro bioassays and chemical analysis. Environ. Pollut. 2017, 220, 1220-1230. [CrossRef]

46. Mišík, M.; Ferk, F.; Schaar, H.; Yamada, M.; Jaeger, W.; Knasmueller, S.; Kreuzinger, N. Genotoxic activities of wastewater after ozonation and activated carbon filtration: Different effects in liver-derived cells and bacterial indicators. Water Res. 2020, 186, 116328. [CrossRef] [PubMed]

47. Neale, P.A.; Munz, N.A.; Aït-Aïssa, S.; Altenburger, R.; Brion, F.; Busch, W.; Escher, B.I.; Hilscherová, K.; Kienle, C.; Novák, J.; et al. Integrating chemical analysis and bioanalysis to evaluate the contribution of wastewater effluent on the micropollutant burden in small streams. Sci. Total Environ. 2017, 576, 785-795. [CrossRef] [PubMed] 